\title{
The Relatively Autonomous Discourse of Law
}

WE HAVE LONG BEEN ACCUSTOMED to think of law as something apart. The grand ideals of justice, of impartiality and fairness, have seemed to remove law from the ordinary, disordered paths of life. ${ }^{1}$ For this reason efforts to unearth connections between law and culture have appeared vaguely tinged with exposé, as though the idol were revealed to have merely human feet.

In recent years, with a firmer sense of the encompassing inevitability of culture, the scandal has diminished, and the enterprise of actually tracing the uneasy relationship of law to culture has begun in earnest. There is an emerging consensus that culture ought to be regarded, in Raymond Williams's words, "as the signifying system through which necessarily (though among other means) a social order is communicated, reproduced, experienced, and explored."2 Culture, we have come finally to believe, is the precondition for the very possibility of human meaning, and is not merely ornamental, but engaged in the hard, practical, and important work of reproducing the social order.

The realization that social order requires the mediation of social meaning, and that social meaning arises through the operation of systems that are simultaneously symbolic and practical, has enabled the study of law to join the larger family of human sciences. It has empowered legal scholars to proceed on the assumption "that the creation of legal meaning-'jurisgenesis'-takes place always through an essentially cultural medium." ${ }^{3}$ It has liberated the legal academy from, in Joseph Vining's eloquent formulation, "projecting an image of law as a set of rules outside, a grid that, could you only tap it with your fingernail, would give out a hard metallic ring" (9). Legal scholarship has in consequence begun to produce a substantial body of work that, like contemporary literary criticism, explores "the social and historic dimensions of symbolic practice" and pushes "beyond the boundaries of the text, to establish links between the text and values, institutions, and practices elsewhere in the culture."4

This scholarship suggests that jurisgenesis cannot be conceived merely as the reflection or reproduction of the ambient culture. As the uniquely "authorized discourse for the state," occidental law attempts to legitimize its coercive bite through distinctive aspirations toward such values as objectivity, neutrality, and rationality. ${ }^{5}$ This aspiration is deeply reflexive, focusing on questions of internal consistency that we have come to subsume under the concept of the "rule of law." 
A fascinating dialectic is thus set in motion, in which our law uses the resources of the larger culture precisely in order to establish its own particular kind of cultural discourse. ${ }^{6}$ In this respect occidental law may accurately be described as a "relatively autonomous" cultural form.?

To conceive the law as a relatively autonomous form of discourse is immediately to glimpse the potential for a new and stimulating agenda of research. Consider, for example, three questions. The first might be called the "boundary question," for it would concern the internal mechanisms by which the boundaries of legal discourse are maintained. Somehow legal discourse manages both to situate itself within the larger culture and at the same time to retain its own distinct discursive identity. To understand how this is accomplished we need to study not merely the interpretive practices of legal actors, but also how these practices are tied to the allocation of power within the legal system.

A second topic for research might be called the "legitimacy question," for it would address the issue of how legal discourse sustains its legitimate authority in society at large. If the boundary question focuses on the distinctive features of legal discourse, the legitimacy question shifts our attention to the functioning of legal discourse within the general culture. It invites us to conceive of legal discourse as "simply one of many competing normative disciplinary discourses, discourses of morality, religion, and social custom" ${ }^{\prime 8}$ and to inquire into the processes by which legal discourse retains its characteristic prestige and power. This inquiry cannot be divorced from the boundary question, for the legitimacy of the law may well depend upon the specific means by which legal discourse establishes its own relative autonomy.

Finally, there is what may be called the "political question," which would concern the practical implications of conceptualizing a world in which meaning has been dissolved into faceless and impersonal systems of discourse. Quite apart from the descriptive accounts of the law implied by the boundary and legitimacy questions, we must also confront the political and moral consequences to ourselves of inhabiting such a world. We need to ask what values the law ought in such circumstances to serve. And of course that inquiry depends upon the darker and deeper question of how political freedom and action, those most irreducibly humanistic of virtues, ought to be conceived when meaning, and therefore identity itself, has been dispersed into the empty matrices of cultural systemics.

These are difficult and pressing questions, driving some of the best and most innovative contemporary legal scholarship. They also form the framework for the essays in this volume. Although these essays are written from a wide variety of disciplinary perspectives-Carla Hesse writes as a historian, Jennifer Nedelsky as a political scientist, Kim Lane Scheppele as a sociologist, Martin Stone as a philosopher, François Ewald as a cultural theorist, and Joseph Vining and myself as legal academics-they nevertheless retain a common focus on the theoretical problematic of the law as a relatively autonomous form of cultural discourse. 
They illustrate in microcosm the emerging possibilities of the interdisciplinary study of law.

Of the three inquiries I have posed, the boundary question is perhaps the most traditional, for it evokes longstanding work in the theory of legal interpretation. Nevertheless in recent decades, as discipline after discipline has taken the "interpretive turn," ${ }^{\prime}$ legal theorists have tended to look outward and to seek to explain legal interpretation on the principles of general hermeneutic theory. ${ }^{10}$ While this effort has had the salutary effect of uncovering shared cultural foundations of the law, it has also, at least in its more extreme manifestations, challenged the relative autonomy of the law, for it would subsume the constitution of legal thought under an undifferentiated cultural methodology.

Joseph Vining's essay in this volume, while conceding the undoubted "convergences" of interpretative practice, nevertheless questions the underlying assumption of this effort, "that interpretation is the same phenomenon or experience whatever its setting" (1). Vining gently calls attention to various distinctive aspects of legal interpretative method: the characteristic absence of a definitive legal text to interpret until one is made visible by processes of legal interpretation; the characteristic authorlessness of various kinds of legal texts; the characteristic use of legal texts to facilitate legal writing.

Of course these facets of legal interpretation correspond to well-developed problematics within what may be called abstract interpretative theory. The "preinterpretative" necessity of identifying a specific legal text illustrates the generic "problem of the frame- of the distinction between inside and outside" posed by the "intertextuality" of texts. ${ }^{11}$ The obscurity of individual legal authors highlights the influential project advanced by Foucault of analyzing the "authorfunction" as "a variable and complex function of discourse." ${ }^{12}$ Reading legal texts in order to use them exemplifies Gadamer's thesis that all interpretation rests on "application."13 But these general correspondences do not vitiate Vining's thesis. The relative autonomy of the law, after all, does not presuppose legal exceptionalism. It instead claims that the concrete form in which abstract methodological issues are presented, experienced, structured, and resolved is distinctive to the law. Vining's essay elegantly illuminates the possibilities of such a claim.

Vining observes the special way in which certain kinds of legal texts gain their "authority" through a form of transcendental personification, by purporting to speak "for the law or for an entity ... that in turn speaks for the law" (6). The observation raises a central methodological issue, which is how this effort to "speak for" the law is sustained. The issue involves not merely questions of hermeneutic method, but also of the relationship between the substance of legal interpretation and that of other forms of cultural discourse. My own contribution to this volume, for example, suggests that in constitutional law the attempt to 
"speak for" the Constitution necessarily entails an appeal to political rather than narrowly legal values. Judicial debates over "theories" of constitutional interpretation may most usefully be seen as conflict over the nature and use of these values. Method and substance, legal and nonlegal forms of discourse, are thus intricately and self-consciously braided together to produce what we immediately recognize as distinctively constitutional patterns of thought.

Jennifer Nedelsky's essay in this volume offers a very different perspective on the relationship between legal and other cultural discourses. She convincingly demonstrates "that the image of protective boundaries as essential to the integrity and autonomy of the self is deep and pervasive in our culture" (168) and that this image permeates and influences legal thought in such disparate areas as property, privacy, and constitutional rights. The connection between law and the general culture is thus shown to function at the level of unconscious metaphoric structures.

The dependence of that connection upon matters of institutional design is deftly illuminated in Kim Lane Scheppele's essay. In the Anglo-American legal tradition, judges are deemed responsible for findings of law, juries for findings of fact. Judges are professionals, trained in the discourse of the law; juries are composed of laypersons, who are supposed to represent the general community. Scheppele demonstrates that there is no ontological distinction between propositions of law and propositions of facts, because "[l]aw and fact are mutually constituting-not simply hard to tell apart" (62). The difference between the two, then, inheres entirely in the law's "way of allocating authority across different sets of actors" (62).

This division of power marks the boundary between professional legal discourse and general "cultural knowledge, background knowledge available in the social world" (63). Because cases must be decided on the basis of both law and facts, this boundary is paradoxically folded into legal practice itself, foreclosing any possibility of internally insulating legal discourse from the influence of the ambient culture. Yet this influence can be controlled and ultimately subordinated to a distinctive professional legal discourse through administrative manipulation of the law/fact distinction.

Scheppele's essay forcefully illustrates the relationship between the legitimacy and boundary questions, for her conclusion is that "[l]egal authority ... rests on the ability of legal narratives to reside simultaneously in the normative universes of legal and nonlegal worlds" (65). For Scheppele, in other words, the cultural legitimacy of the law depends upon interpretative practices that maintain a certain homology between legal discourse and other forms of culture.

Nedelsky agrees, noting that "American constitutionalism has the power it does in part because its metaphoric structure resonates so powerfully with the 
fears and (elusive because illusory) goals of the separative self" (181). But Nedelsky also argues for the adoption of "new symbols, myths, and metaphors to replace the old" (181). Her work thus presupposes that the law is not necessarily bound by the discourse of the general culture, but can instead become an independent force for change. In suggesting this consequence Nedelsky's article points toward the growing literature of "critical" legal sociology, which is concerned with documenting the vast extent to which "legal discourses constitute social life," in the sense that "the law and legal institutions can be seen as structures of meaning that radiate throughout social life and serve as part of the material people use to negotiate their understanding of everyday events and relationships." 14 The clear implication is that legal legitimacy may have other foundations than mere homology.

Two other articles in this volume, those by François Ewald and Carla Hesse, reflect this same divergence of perspectives. Ewald is concerned with explicating the following suggestive passage from Foucault:

Another consequence of [the] development of bio-power was the growing importance assumed by the action of the norm, at the expense of the juridical system of the law. Law cannot help but be armed, and its arm, par excellence, is death; to those who transgress it, it replies, at least as a last resort, with that absolute menace. The law always refers to the sword. But a power whose task is to take charge of life needs continuous regulatory and corrective mechanisms. ... Such a power has to qualify, measure, appraise, and hierarchize, rather than display itself in its murderous splendor; it does not have to draw the line that separates the enemies of the sovereign from his obedient subjects; it effects distributions around the norm. I do not mean to say that the law fades into the background or that the institutions of justice tend to disappear, but rather that the law operates more and more as a norm, and that the judicial institution is increasingly incorporated into a continuum of apparatuses (medical, administrative, and so on) whose functions are for the most part regulatory. A normalizing society is the historical outcome of a technology of power centered on life..$^{15}$

Foucault distinguishes the violence of the law, which for him characterizes the "juridical system of the law," from its capacity to organize, administer, and constitute forms of social life, which he views as an essentially regulatory mechanism. Regulation can occur at the specific level of the "disciplines," which involve the "anatomo-politics of the human body," and which center "on the body as a machine: its disciplining, the optimization of its capabilities, the extortion of its forces, the parallel increase of its usefulness and its docility, its integration into systems of efficient and economic controls." Regulation can also occur at the more general level of "a bio-politics of the population," which centers instead on "the species body, the body imbued with the mechanics of life and serving as the basis of the biological processes: propagation, births and mortality, the level of health, life expectancy and longevity, with all the conditions that can cause these to vary." For Foucault these "two poles" of the "disciplines of the body and the regulations of 
the population" describe the reach of what he calls "bio-power," which is "the organization of power over life."16

Bio-power functions through the operation of norms, and Ewald's fascinating article explicates the concept of the norm as "that form of the common standard produced through the group's reference to itself" (159). Norms are characterized simultaneously by positivism, relativity, and polarity (155-58). Understood in this fashion, norms make possible the regulatory apparatuses of modern life, ranging from "the panoptical logic of discipline," to "the probabilistic schema of insurance," to the "communicative logic" of industrial standardization (154). And, in particular, norms are for Ewald what make "law possible in modern societies" (155). The possibility and legitimacy of the law are thus perceived as dependent upon the congruence between legal discourse and the more general structures of bio-power. ${ }^{17}$

Carla Hesse presents a quite different perspective. Her purpose is to challenge Foucault's influential hypothesis that "the modern concept of the author" emerged "historically as the cultural incarnation of a new axis in sociopolitical discourse: the inviolable relation between the rights-bearing individual and private property" (109). As developed by the subsequent work of Martha Woodmansee and Mark Rose, Foucault's hypothesis requires a particular interpretation of the emergence of copyright law as reflecting "new bourgeois socio-economic relations and cultural values" (110). Hesse questions this view. Her careful and authoritative reconstruction of the emergence of French copyright law during the Revolution demonstrates that there were in fact competing cultural understandings of the author, as private proprietor and as public servant. The law did not passively reflect one or the other of these understandings, but rather actively and creatively compromised between them. Hesse concludes that we "need a more complex view of the relationship between the law and cultural change, one that accounts for the political as well as the socio-economic forces at work in the reshaping of the legal world" (131).

The realm of the political is of course that of action and decision. By suggesting the dependence of the law upon the political, Hesse implies that we (at least in some degree) choose our legal fate. Like Nedelsky, Hesse envisions a law which does not merely reflect more general cultural domains, but rather actively affects them. But what, we may ask, is the source of the law's authority in such circumstances? Although Hesse does not explicitly address this question, her references to the Revolution make it plain enough that at least one important source is what Foucault calls the law's "murderous splendor." Behind the law's immense power of cultural constitution always lies the "armed" violence of the state.

It is important to observe that Scheppele, Nedelsky, Hesse, and Ewald are addressing the legitimacy question at vastly different levels of abstraction. Scheppele is concerned with the narrative resolution of particular cases; Hesse with the 
cultural background of specific laws; Nedelsky with the generic metaphoric patterns that underlie legal reasoning; and Ewald with the connection between law and the structural components of cultural order. Yet the essentially dialectical relationship of law to culture can be found at each of these levels. Pierre Bourdieu has offered a striking rendition of that relationship:

The law is the quintessential form of "active" discourse, able by its own operation to produce effects. It would not be excessive to say that it creates the social world, but only if we remember that it is this world which first creates the law. It is important to ascertain the social conditions-and the limits-of the law's quasi-magical power. ... [T] he schemas of perception and judgment which are at the origin of our construction of the social world are produced by collective historical labor, yet are based on the structures of this world themselves. . . . Our thought categories contribute to the production of the world, but only within the limits of their correspondence with preexisting structures. Symbolic acts of naming achieve their power of creative utterance to the extent, and only to the extent, that they propose principles of vision and division objectively adapted to the preexisting divisions of which they are the products. ${ }^{18}$

The essays in this volume well illustrate this ceaseless dialectic.

Carla Hesse's tale of the creation of French copyright law relates how citizens, engaged in political controversy, used the law to embody and express their decisions and compromises. The underlying image is the familiar one of law attendant upon a politics that occurs in a realm of exchange among fully constituted subjects. This image funds most contemporary constitutional thought and scholarship. ${ }^{19}$ My own essay in this volume, for example, works in the tradition of this image.

The image is logically compatible with the concept of law as a relatively autonomous discourse. Cultural systems, however necessary for the creation of human meaning, can be conceptualized as a medium of political exchange and hence of legal valorization. They can be analogized to a form of language that makes possible expressions of political and legal action. What I have called the "political question," therefore, need assume no transcendent difficulties, but may merely pose the problem of politics as usual: What is to be done?

The situation is quite otherwise, however, if cultural discourse is understood to constitute and to undermine the subjectivity of the very citizens who seek to engage in politics. If "power," to use Foucault's words, "makes individuals subjects," [begins] to seem remarkably unfree, the ideological product of the relations of power in a particular society."21 The issue is not merely one of historical determinism and consequent political passivity, ${ }^{22}$ but, more deeply, of the possible meaning of politics for a self that is merely "a cultural artifact." ${ }^{23}$ It would seem 
that any potential political outcome would merely reinscribe initial conditions of deprivation. Hence Foucault:

The system of right, the domain of law, are permanent agents of the relations of domination, these polymorphous techniques of subjugation. Right should be viewed, I believe, not in terms of a legitimacy to be established, but in terms of the methods of subjugation that it instigates. ${ }^{24}$

In such circumstances the force of the political question strikes with a vengeance.

Foucault himself speaks of the relationship between power and freedom as "an 'agonism," " a "relationship which is at the same time reciprocal incitation and struggle; less of a face-to-face confrontation which paralyzes both sides than a permanent provocation." There can be on this account no "essential freedom," only a perpetual conflict between "the recalcitrance of the will" and the power that makes the self possible. ${ }^{25}$ This agonistic conflict finds its reflection in "'oppositional' American criticism," with its emphasis "on indeterminant negativity." ${ }^{26}$ It can also be seen in the recent marriage of Marxism and deconstruction that proffers the possibility of "permanent revolution" and "an infinite progress in socially reconstructive action." 27

These perspectives are the most recent manifestation of a tradition stretching back to figures like Fichte, Schiller, Schelling, in which nonconsensual influences on the self are perceived as coercive invasions of the autonomy of the subject, to be overcome through political liberation. ${ }^{28}$ The longing to overcome a dehumanized world is given a distinctive post-modernist twist when coercive external structures are also and simultaneously seen as constitutive of the very self that seeks autonomy. Political emancipation therefore necessarily turns Sisyphean, aptly described in images of the "permanent" and the "indeterminant."

In the legal academy this form of politics has been most profoundly and influentially explored by Roberto Mangabeira Unger, the acknowledged intellectual leader of the important Critical Legal Studies Movement. Unger's first book powerfully explored the "antinomies" of liberal thought, contradictions between "reason and desire," "rules and values," and "theory and fact." It sought to overcome these antinomies through the "regulative ideal" of a "universal community" in which "the sense of immanent order would be brought into harmony with the capacity of criticism or transcendence" and "the antagonism of the individual with the social aspect of personality" would be dissolved in "each person's recognition of the concrete individuality of his fellows." ${ }^{29}$ Fully aware of the unreality of this ideal, the book closed with a famous prayer of frustration:

When philosophy has gained the truth of which it is capable, it passes into politics and prayer, politics through which the world is changed, prayer through which men ask God to complete the change of the world by carrying them into His presence and giving them what, left to themselves, they would always lack....

But our days pass, and still we do not know you fully. Why then do you remain silent? Speak, God..$^{30}$ 
Unger's most recent work, an impressive trilogy entitled Politics: A Work in Constructive Social Theory, ${ }^{31}$ assays a practical political and legal solution to these antinomies. In Politics, however, the force of the antinomies has been reduced to a single master contradiction: the self requires context for its substantive realization, but all context unduly limits and constrains the self. ${ }^{32}$ Unger's solution to this dilemma is to propose a highly elaborated form of politics and law that collapses "the distance between context-preserving routine and contexttransforming conflict," thereby enabling "the assertion of will over custom and compulsion." ${ }^{38}$ By designing institutions that "respect and encourage our contextsmashing abilities," ${ }^{44}$ Unger drives "the idea of society as artifact to the hilt."35

Unger's work, in short, represents the most developed institutional and legal vision of the kind of permanent "agonism," the endlessly repetitive struggle between will and power, that is so powerfully attractive for the post-modern left. It is a vision that is deeply and movingly analyzed by Martin Stone's essay in this volume. Stone's query is whether this agonism can properly be called political at all, for it urges no particular action or program other than the reiterated rehabilitation of the will. The will, however, is only what makes politics possible; the practice of politics consists in giving the will specific and concerted direction. "We might read Unger's theory," Stone therefore suggests, "as a rigorous formalism: not as a politics but as a grammar that retraces the seam, circles the rim, of the political as such" (100). Stone's disturbing implication is that the agonism of the post-modern left ought to be seen as a retreat from politics, as an anguished effort to buttress the failing "fiction" of the autonomous self that would make redemptive politics possible (94-95).

And yet we do go on. Jennifer Nedelsky's essay concludes this volume with a glimpse of a "genuine option": We could be "radically transformed if we were to come to see ourselves as 'inseparable from all other beings in the universe" (184, 183). We could "approach the daunting task of reimagining the rhetoric of law and freedom" (182). From within the feminist tradition, Nedelsky seizes the occasion of the political question for a classically clarion call to decision and to action. Traversing the external understandings necessary for apprehending the boundary and legitimacy questions, her work nevertheless retains what Stone would surely view as a quintessentially political commitment. The possibility of that commitment does not ring falsely, at least to me. In this way the old struggle for particular values, for particular forms of politics and law, continues even in the teeth of the discursive dissolution of the self. Were it otherwise all our comprehension of the relative autonomy of the law would not much matter. 
1. See Carol J. Greenhouse, "Just in Time: Temporality and the Cultural Legitimation of Law," Yale Law Journal 98 (1989): 1631-51.

2. Raymond Williams, Culture (Glasgow, 1981), 13.

3. Robert M. Cover, "Foreword: Nomos and Narrative," Harvard Law Review 97 (1983): 11.

4. Stephen Greenblatt, "Culture," in Frank Lentricchia and Thomas McLaughlin, eds., Critical Terms for Literary Study (Chicago, 1990), 230, 226.

5. See Zillah R. Eisenstein, The Female Body and the Law (Berkeley, 1988), 20, 42-51; and Talcott Parsons, Sociological Theory and Modern Society (New York, 1967), 510.

6. To the extent that all cultural discourses "distribute the effects of power," they, like law, attempt to domesticate themselves as "'self-evident' and 'commonsensical' " (Paul A. Bové, "Discourse," in Lentricchia and McLaughlin, Critical Terms for Literary Study, $58,54)$. What distinguishes law, therefore, is both the particular content of the legitimacy it seeks and the particular way in which it seeks to attain it.

7. Robert W. Gordon, "Critical Legal Histories," Stanford Law Review 36 (1984): 101. See Isaac D. Balbus, "Commodity Form and Legal Form: An Essay on the 'Relative Autonomy' of the Law," Law and Society Review 11 (Winter 1977): 571-88. Pierre Bourdieu situates the relative autonomy of the law in the space between "formalism," which "sees the law as an autonomous and closed system whose development can be understood solely in terms of its "internal dynamic," and "instrumentalism," which "conceives of law as a reflection, or a tool in the service of dominant groups" (Pierre Bourdieu, "The Force of Law: Toward a Sociology of the Juridical Field," The Hastings Law Journal 38 [1987]: 814).

8. Peter Goodrich, Reading the Law: A Critical Introduction to Legal Methods and Techniques (London, 1986), 20.

9. See Daniel Bell, “The Turn to Interpretation: An Introduction," Partisan Review 51 (1984): 215-19.

10. See, e.g., William N. Eskridge, Jr., "Gadamer/Statutory Interpretation," Columbia Law Review 90 (1990): 609-81.

11. Jonathan Culler, On Deconstruction: Theory and Criticism after Structuralism (Ithaca, 1982), 193-200, 129-34.

12. Michel Foucault, "What Is an Author?" in Josué V. Harari, ed., Textual Strategies: Perspectives in Post-Structuralist Criticism (Ithaca, 1979), 158.

13. Hans-Georg Gadamer, Truth and Method (London, 1975), 274-305. Gadamer calls the intended application of legal interpretation "exemplary" of "all other understanding."

14. David M. Trubek, "The Handmaiden's Revenge: On Reading and Using the Newer Sociology of Civil Procedure," Law and Contemporary Problems 51 (Autumn 1988): 124.

15. Michel Foucault, The History of Sexuality, vol. 1, An Introduction, trans. Robert Hurley (New York, 1980), 144.

16. Ibid., 139-40.

17. Ewald's position is entirely consistent with that of Foucault, who writes: "I wish to suggest that one must analyze institutions from the standpoint of power relations, rather than vice versa, and that the fundamental point of anchorage of the relationships, even if they are embodied and crystallized in an institution, is to be found outside the institution" (Michel Foucault, "The Subject and Power," in Hubert L. Dreyfus 
and Paul Rabinow, Michel Foucault: Beyond Structuralism and Hermeneutics [Chicago, 1983], 222).

18. Bourdieu, "The Force of Law," 839.

19. See Frank Michelman, "Law's Republic," Yale Law Journal 97 (1988): 1493-1537; Robert Post, "The Constitutional Concept of Public Discourse: Outrageous Opinion, Democratic Deliberation, and Hustler Magazine v. Falwell," Harvard Law Review 103 (1990): 601-86; and Jürgen Habermas, The Theory of Communicative Action (Boston, 1981).

20. Foucault, "The Subject and Power," 212.

21. Stephen Greenblatt, Renaissance Self-Fashioning: From More to Shakespeare (Chicago, 1984), 256.

22. Frank Lentricchia, "Foucault's Legacy-A New Historicism?" in $\mathrm{H}$. Aram Veeser, The New Historicism (New York, 1989), 231-42. Compare Mark Maslan, "Foucault and Pragmatism," Raritan 7 (1988): 94-114.

23. Greenblatt, Renaissance Self-Fashioning, 256.

24. Michel Foucault, Power/Knowledge: Selected Interviews and Other Writings (New York, 1980), 96.

25. Foucault, "The Subject and Power," 221-22.

26. Catherine Gallagher, "Marxism and the New Historicism," in Veeser, The New Historicism, 41. See Catherine Gallagher, "Politics, the Profession, and the Critic," Diacritics (Summer 1985): 37-43.

27. Michael Ryan, Marxism and Deconstruction: A Critical Articulation (Baltimore, 1982), 19.

28. Bernard Yack, The Longing for Total Revolution: Philosophic Sources of Social Discontent from Rousseau to Marx and Nietzsche (Princeton, 1986).

29. Robert Mangabeira Unger, Knowledge and Politics (New York, 1975), 260.

30. Ibid., 294-95. For a discussion of the theological dimensions of Unger's thought, see Stanley Fish, "Critical Legal Studies: Unger and Milton," Raritan 7 (Fall 1987): 1-20; and Stanley Fish, "Critical Legal Studies (II): Roberto Unger's Transformative Politics," Raritan 7 (Winter 1988): 1-24.

31. The trilogy consists of Social Theory: Its Situation and Its Task (Cambridge, 1987), False Necessity: Anti-Necessitarian Social Theory in the Service of Radical Democracy (Cambridge, 1987), and Plasticity into Power: Comparative-Historical Studies in the Institutional Conditions of Economic and Military Success (Cambridge, 1987). For a discussion of the trilogy, see Robin W. Lovin and Michael J. Perry, eds., Critique and Construction: A Symposium on Roberto Unger's Politics (Cambridge, 1990).

32. Unger, Social Theory, 18-22.

33. Ibid., 6-7.

34. Unger, False Necessity, 510 . In a strikingly innovative move, Unger suggests the creation of "destabilization rights" that would "protect the citizen's interest in breaking open the large-scale organizations or the extended areas of social practice that remain closed to the destabilizing effects of ordinary conflict and thereby sustain insulated hierarchies of power and advantage" (ibid., 530).

35. Unger, Social Theory, 1. 
